\title{
Functional Cinematic Elements in Works of Alberts Bels: Allusions, Themes and Clichés
}

\author{
JÜLIJA DIBOVSKA
}

\begin{abstract}
Alberts Bels is a Latvian author whose literary works contain the most notable cinematic elements in Latvian literature. He is also one of those authors who uses a lot of functional cinematic elements alongside with structural ones. Both of these cinematic elements frame the intertextual depth of a text and also make characters dynamic, understandable and ironically toned for a reader.
\end{abstract}

Keywords: cinematic elements, functional, allusions, clichés, irony

In the $20^{\text {th }}$ century there were significant changes going on in the relationship between the visual culture and literature; fine arts like painting, sculpture and music have long enough been the companions for the literature although they became even more significant factors of influence at the beginning of $20^{\text {th }}$ century and then, as some researchers claim, they still have a big impact on a written word today when visual culture has become the part of our everyday life. (Brēmere 2013: 4) After the triumph of photography in the middle of the $19^{\text {th }}$ century it was cinema that represented the technological changes in culture. From the beginning of the $20^{\text {th }}$ century cinema grew up as another important art that entirely changed the way people see the world:

Then came the film and burst this prison-world asunder by the dynamite of the tenth of a second, so that now, in the midst of its far-flung ruins and debris, we calmly and adventurously go traveling. With the close-up, space expands; with slow motion, movement is extended. The enlargement of a snapshot does not simply render more precise what in any case was visible, though unclear: it reveals entirely new structural formations of the subject. So, too, slow motion not only presents familiar qualities of movement but reveals in them entirely unknown ones "which, far from looking like retarded rapid movements, give the effect of singularly gliding, floating, supernatural motions". (Benjamin 1968: 236) 
Functional Cinematic Elements in Works of Alberts Bels: Allusions, Themes and Clichés

As an offspring of fine arts, theatre and literature and also as a product of technological progress cinema had become the most controversial new art in the $20^{\text {th }}$ century; but it is also one of the most popular mediums of storytelling.

The relationship between cinema and literature is considered to be dual: not only has literature given cinema most of its narrative strategies from which cinema has developed the main principles of montage and specific genres. Also, literature started to borrow these specifically cinematic elements to tell the stories including those about the world of cinema or, for example, to tell about the modern man who is connected with cinema in his everyday life or sees the world with the gaze of the spectator. ${ }^{1}$

Authors of the $20^{\text {th }}$ and the $21^{\text {st }}$ century (for example, James Joyce, Franz Kafka, Mikhail Bulgakov, F. Scott Fitzerald, Ernest Hemingway, William Faulkner, Elizabeth Bowen, Katherine Mansfield etc.) have widened the possibilities of literature and its cultural weight by integrating or imitating in their writing different cinematic techniques, principles of montage and scriptwriting, as well as images of directors, actors, scriptwriters and everything else from the cinema industry or by reflecting about the significant films and motifs.

Although cinematic elements in literary texts are rarely recognized and noted, they can give some powerful, interdisciplinary tools in the hands of literary scholars; as by analyzing cinematic elements in literary texts, a reader can achieve more information about formal, structural qualities of the text itself and about its intertextual value.

One can get an insight into some of the cultural and artistic tensions between literature and cinema, for example, in the former Soviet Union - by looking at the range of literary texts of a particular author who is known for his interest or connection with cinema and for the use of cinematic elements in his writing. One of such contemporary authors in Latvian literature is Alberts Bels (1938). Between the years 1966 to 2005 he wrote fourteen novels and three works of short fiction. He is mostly known for his books that were written in Soviet times - like novels Büris (The Cage, 1972), Saucēja balss (The Voice of the Herald, 1973), Izmeklètājs (The Investigator, 1976) and others. Besides being a passionate cinema-goer, Alberts Bels also has an experience in scriptwriting - in the late 1960s he was studying in Moscow at the Higher Courses for Screenwriters. One of his unscreened scripts was published in the literary magazine Karogs in 1974; he is also the author of a script based on his novel Saucēja balss that has been screened into a feature film in 1974 (Uzbrukums slepenpolicijai, dir. O. Dunkers). This short insight into Bels' biography is necessary to underpin the potential of cinematic point of view

1 For example, cinematic characters in books by Vladimir Nabokov. See Wyllie 2003. 
DIBOVSKA

and familiarity with cinematic imaginery that might be seen in his artistic manifestations.

Speculating about cinematic influence on literature - we might say that there are no literary works in the $20^{\text {th }}$ and the $21^{\text {st }}$ century that have not been influenced by the cinema. It is a fact but it is not a very productive observation for research. If we want to look at the general cinematic influence in literature, there has to be a selection made to make such research possible and meaningful. The selection of works when solving the problem of relationship between cinema and literature imply the observation of many obvious formal marks: these marks include the answers to the question - what are those cinematic elements that could be found in text and what are they rather not. If we look at the relationship between the two media, we have to consider concrete aspects that rather could be found and detected in the literary text.

Almost all researchers claim that cinematic elements in literary texts are the features of author's individual style (Mart'janova 2001: 7; Gibson 2001: 8; Nettelbeck 2006: 45) - after all cinema could be seen as the individual experience as well as the individual reflection of the cinematic clichés of mass culture. But the artistic expression of this individual experience as well as the way cinema influences the mind and the work of the writer are hard to detect without dividing cinematic elements into structural and functional ones. Such researchers as Irina Martjanova, Collin Nettlebeck and Barbara Wyllie employ structural methods. They have built their researches by dividing cinematic elements into two parts.

1) Structural elements are those of cinematic narrative; these elements are based on the structure of narrative and composition of literary work - they introduce a reader to the cinematic point of view - whether it is a camera-like view or directors-like vision, a straight montage of different short "cuts": "One sequence is aural, the other visual, and yet because they both have to be read, the effect is analogous to film montage where, for instance, two parallel sequences temporarily fill the screen." (Seed 1984: 183) These elements mostly exclude very long passages about the inner world of the heroes; they concentrate on the outer observation of concrete things and actions; if the narrative is based on a camera-like vision, a reader can also get information only about things and actions that camera usually is able to "see" and "hear". These structural cinematic elements are shown by the use of syntax and even graphic markers that are different from the usual language in literary works (like new paragraphs to show different "scenes" and actions); structural cinematic elements could be seen as the features of scriptwriting in literary work that did not intend to be a script. (Mart'janova 2001: 28-36) 
Functional Cinematic Elements in Works of Alberts Bels: Allusions, Themes and Clichés

2) Functional cinematic elements are the most notable in a literary work; they function as cinematic images, allusions, symbols, motifs and themes, even cinematic ekphrasis (Seigneuret 1988: 248). These elements are usually naturally connected to the plot of a literary work and therefore they could function only in a definite context. They show the level and value of the intertextuality of a significant literary work - even if the author unconsciously mentions a film, image or scene from a film or some cinematic themes, he still places his literary text in the range of other concrete texts and works of art. Because of their contextual significance, functional cinematic elements can be regarded as secondary in relation to structural cinematic elements which represent changes in the poetics of concrete authors' writing. Cinematic allusions and themes usually are just the signals for the deeper cinematic influence on the text. However, structural and functional cinematic elements in literature mostly occur and function side by side.

Both of these groups of cinematic elements are used in the literary works of Alberts Bels. In this article, the focus is on the functional cinematic elements in Bels's prose.

It is interesting that Bels uses functional cinematic elements mostly in works written in the Soviet period. Of course, allusions to contemporary Soviet and foreign films can be found in those novels and short stories which tell about the modern Soviet man.

But paradoxically - structural cinematic elements are more common in his works than functional ones. For example, a lot of functional cinematic elements can be found in the prose of Bels contemporaries, Latvian writers Zigmunds Skujiņš and Margeris Zariņš. These writers mention concrete films and even scenes in some of their works but without reckonizable use of structural cinematic elements. What brings together the use of functional cinematic elements in the prose of Skujinšs, Zarinš and Bels is the irony or even parody mode in which cinema and concrete feature films or film genres are displayed. For example, Bels mentions Tarzan as the film that the heroes of his eco-novel Saknes (The Roots, 1981) have watched in their youth; somehow the heroes of the book behave as "Tarzans" who live in harmony with nature and try to protect it from poachers.

Another object of irony, certainly, is the images of actors. Zaringš and Skujiňš use this imaginary a lot while Bels shows mostly heroes who are likely to be called "directors". In his early short story Kiegelis (The Brick, 1968) Bels pictures the scene in the Soviet cinema school - as the young man who wants to become a film director takes exams and tries to impress an exam committee by telling the story from the "director's point" of view and then by playing the role of football goalie. Ironically he acts so well and plays the falling goalie very well 
DIBOVSKA

but in the end he fails the film director exam itself. And it is the gentle irony of the author that reveals the tragicomic world of making cinema.

As it was mentioned - functional and structural cinematic elements work in Bels' texts side by side, completing each other and giving the signals to the closer reading of the text. One of the most common cinematic characters in Bels' prose is the multitalented, ironically or even sarcastically pictured man who represents the possibilities of contemporary technologies and needs. This kind of man occurs in the novel Saucēja balss - he is a spy called "Blue-pants" (Zilbiksis). Bels pictures him like a very talented amateur artist and even a multifunctional personification of cinema as a synthetical art. These abstracts show how Bels uses the compositional principles of photography and cinema, how he adds optical changes in the world view of a character and even presents a theoretical approach to the cinema-like art:

Then Bluepants began to practice photography, showing all he knew about composition, the choice of tones, the building of the frame,the psychological approach $[. .$.$] ; in the picture that was enlarged seven times he has found the$ fulfillment of his desire [...]; Bluepants said he was writing an interesting paper on the fusion of all arts. He has demonstrated this chance to fuse all the arts together in his living room that was also his workshop. Here was his easel always with an unfinished painting on it, very good for the amateur, beside it was the unfinished sculpture. Of course, here also has a piano with a new opus on it, needless to say - Bluepants was a good storyteller, he could tell about the whorehouses in the Pacific ocean as well as the New York art galleries. (Bels 1973: $120-122$ )

The modern man in Bels' prose is influenced by his cultural environment the more ironically the author looks at his characters the more they are being grown by the values of the Soviet mass culture. In one of his first short stories Bels writes: "Almost all people are pieces of clay. From the start it is the cradle, the house they live in, parents, then school, newspapers, public ideas, radio, cinema, media and so on until the man is changed and shaped, not what he used to look like." (Bels 1968: 8) Cinema beside other media and social influences is one of the most notable features in Bels' short fiction characters' life. By following the prose tradition of the Latvian writer Eriks Ādamsons, Bels points at the weakest and strangest characters possible. Just like the strange and spying art amateur Bluepants who imagines he is the synthetic personification of all arts, another Bels character named "Zanis of Harmonicas” (Ermoniku Žanis) comes to Riga from the countryside and starts to play different roles 
Functional Cinematic Elements in Works of Alberts Bels: Allusions, Themes and Clichés

like an actor and acts like he is actually talking to his imaginary lovers on the street telephone:

He wandered further. All the films of this week are watched, he doesn't want to return home, there is no girl; and he is a Don Juan! [... One night he was the passionate lover who wanted to meet his love, another - the bitter husband who doesn't want to let his wife in, then - a shy lad who is hunted by an experienced widow. (Bels 1968: 216)

Cinema in Bels' prose is a source of act-models and material for imitations. This visionary world of the cinema also gives strange lies to a reader besides the real facts - a character in the short story "Spēks ūsās" ("It's All About the Moustache", 1966) is a collector of old purses, and it is strange that he says he owns the purse of a really existing Soviet deputy and also the purse of a "famous actress Vilma Rineta" (Bels 1966: 78). But the problem is there is no such actress in reality; she stays unknown to the reader today and that way she is also imaginary for the author.

Another character that represents Bels's ironical look at the cinema through the functional cinematic elements in prose comes from his novel Poligons (The Range, 1977). It is not only a cinematic ekphrasis of a hardly recognizable Soviet war film that the author adds to this text and not even the longest cinematic text fragment that makes this novel special among other works by Bels. What makes Poligons special is also the very cinematic and controversial image of a scriptwriter named Pingerots who is sarcastically depicted as the feature of the late Soviet cinema production - a multitalented amateur of every art: "He could sing, well enough to imitate famous tenors from La Scala, he could tell stories maybe even better than Conan Doyle, he knew desire as well as Boccaccio, he could be as talented as Antonioni, active as Don Juan, mysterious as major Pronin (or James Bond, if you like)." (Bels 1977: 64) Bels has evidently been among those passionate film-goers of the 1970s who beside the Soviet war films also knew the works by Michelangelo Antonioni and novels or films about James Bond. Bels also reflects on some cinematic and mass culture clichés - for example, on the cinematic, mostly Freudian, image of a woman in man's mind:

Pingerots was laughing that the only sport object for a woman is a man, that the only ball that the women from all over the world would gladly play is a man. If a woman shoots precisely, he said, then it is only because she is aiming at a man; 
DIBOVSKA

if she runs fast - she is going to catch a man; if she fights with a rapier - she wants to stab a man's heart with it; if she skates, that it is not for fun, but for a man to twist his mind while decoding the complicated signs on ice.

It was a banal sense of a woman, based on pulp fiction and erotic films but it existed [...] (Bels 1977: 35)

It is not a coincidence that the novel with the most concrete cinematic allusions and cinematic and mass culture clichés also contains some of the best and yet experimental structural cinematic elements like montage and cameralike point of view. As it was mentioned, functional and structural cinematic elements support each other in literary texts.

Structural and functional cinematic elements could have a different undertone in authors' work: functional cinematic elements are mostly used to declare Bels' ironic or sarcastic view of the characters, of his own century, contemporaries and their morals; while structural cinematic elements work as part of a cinematic experiment. The result of mostly all of Bels' experiments and irony is the notion that man is influenced by his environment and culture and can be described by mentioning only a few notable films, directors, characters, books and other elements of culture. Culture, and especially film culture, means a lot to the writer, as it meant a lot to his time. Film characters and types, situations and genre can shape Bels' characters into more understandable and yet ironically pictured individuals (Tarzan - for people who live in the woods, Antonioni - for those who know passion in love, erotic film logics for men).

Bels' own experience as a film viewer that could be gleaned from the functional cinematic elements in his prose puts structural cinematic elements into a new interpretative context - for example, by knowing that Bels has seen and then has admired films by Michelangelo Antonioni, we can look at the camera point of view in his works as having possibly been influenced also by this famous director. This can work both ways - if structural cinematic elements like montage, script-like text and camera point of view make the literary text dynamic and places a reader literally in the seat of a cinema viewer, this reader enjoys Bels' texts using her/his own cinematic experience, picturing scenes from the previously watched films, adding information about the style of particular directors, actors and cameramen. All these aspects deepen the understanding of the literary work and also its reception. Functional cinematic elements like allusions, images and themes are the most notable elements to detect cinematic influence in literary texts and to find structural cinematic elements as well as their interaction with functional ones. 
Functional Cinematic Elements in Works of Alberts Bels: Allusions, Themes and Clichés

\author{
Jūlija Dibovska \\ j.dibovska@gmail.com \\ Tinuzu 14-100 \\ LV-1021 Rìga \\ LATVIJA
}

\title{
Works Cited
}

Bels, A. 1966. Spēks ūsās. - Spēles ar nažiem. Rīga: Liesma, 76- 85.

Bels, A. 1968. "Es pats” līdzenumā. - "Es pats" lìdzenumā. Rīga: Liesma, 5- 9.

Bels, A. 1968. Ermon̦iku Žanis. - "Es pats” lìdzenumā. Rìga: Liesma, 211- 220.

Bels, A. 1973. Saucēja balss. Rìga: Liesma.

Bels, A. 1977. Poligons. Rìga: Liesma.

Benjamin, W. 1968. The Work of Art In The Age of Mechanical Reproduction. W. Benjamin, Illuminations. New York: Houghton Mifflin Harcourt, 217-252.

Brēmere, I. 2013. The Verbal Representation of Fine Art Objects in the Latvian Poetry of Early $20^{\text {th }}$ Century. [Dissertation.] Riga: Latvian University.

Gibson, M. C. 2001. Cinematic Techniques in the Prose Fiction of Beatriz Guido. Boston: Boston University.

Mart' janova, I. 2001. Kinovek russkogo teksta: paradoks literaturnoj kinematografičnosti. Sankt-Peterburg: SAGA. = Мартьянова, И. 2001. Киновек русского текста: парадокс литературной кинематографичности. Санкт-Петербург: САГА.

Nettelbeck, C. 2006. Modiano's Style: Novelist in the Age of Cinema. - French Cultural Studies, Vol. 17, No. 1, 35-54.

Seed, D. 1984. Media and Newsreels in Dos Passos' U.S.A. - The Journal of Narrative Technique, Vol. 14, No. 3, 182-192.

Seigneuret, J.-C. 1988. Cinema. - J.-C. Seigneuret, Dictionary of Literary Themes and Motifs, A-J. New York: Greenwood Press, 248-257.

Wyllie, B. 2003. Nabokov at the Movies: Film Perspectives in Fiction. Jefferson,. N.C.: McFarland. 